\title{
Population abundance of pomegranate aphid, Aphis punicae (Homoptera: Aphididae), predators in Southwest of Iran
}

\author{
S. Yaghobi, A. Rajabpour, N. Zandi Sohani \\ Department of Plant Protection, Faculty of Agriculture, Agricultural Sciences and Natural Resources University of \\ Khuzestan, Ahwaz, Iran
}

\begin{abstract}
Pomegranate aphid, Aphis punicae Passarini (Hom., Aphididae) is an important pest of pomegranate in Iran. Predators play critical role in natural control of the pest. In this study, seasonal population dynamics of the aphid predators were investigated during two years $(2016 / 2017)$ in Ilam province, southwest of Iran. Samplings were bi-weekly performed in an experimental pomegranate orchard. Four insect predators, Coccinella septempunctata L., Oenopia congelobata L. (Col., Coccinellidae), Xanthogramma pedisseguum Haris (Dip., Syrphidae) and Chrysoperla carnea Stephens (Neu., Chryspidae) were identified as predators of $A$. punicae in Ilam. The natural enemies occurred during March to May in both years. The highest and the lowest densities were belong to $X$. pedisseguum and $O$. congelobata,
\end{abstract}

Correspondence: Ali Rajabpour, Department of Plant Protection, Faculty of Agriculture, Agricultural Sciences and Natural Resources University of Khuzestan, 63417-71167 Ahwaz, Iran

Tel./Fax: +98.6136522425.

E-mail: rajabpour@ramin.ac.ir

Key words: Pomegranate orchard, aphid, Natural enemies, seasonal population dynamics, IPM.

Contributions: the authors contributed equally.

Conflict of interest: the authors declare no potential conflict of interest.

Funding: The research was financially supported by Khuzestan Agricultural Sciences and Natural Resources University (grant no. 9428414).

Received for publication: 29 May 2018.

Revision received: 8 June 2018.

Accepted for publication: 8 June 2018 .

(C) Copyright S. Yaghobi et al., 2018

Licensee PAGEPress, Italy

Journal of Entomological and Acarological Research 2018; 50:7583

doi:10.4081/jear.2018.7583

This article is distributed under the terms of the Creative Commons Attribution Noncommercial License (by-nc 4.0) which permits any noncommercial use, distribution, and reproduction in any medium, provided the original author(s) and source are credited. respectively. Results of the study can be used for developing integrated pest management program of $A$. punicae in pomegranate orchards.

\section{Introduction}

The pomegranate tree, Punica granatum L. is attacked by several insect species which decrease the quality and quantity of its product (Rouhani et al., 2013). The pomegranate aphid, Aphis punicae Pass (Homoptera: Aphididae), is a major pest of pomegranate groves in Iran (Rouhani et al., 2013; Ahmadi \& Pour Javad, 2016). Adults and nymphs of the pest feed on leaves, inflorescences and fruits. Infestation by aphids result in pale and curled leaves; retard development and fallen flowers (Moawad \& Al-Barty, 2011).

Natural enemies (NEs) play an important role in natural control of aphids (Smith et al., 1997). Many arthropod predators, especially insect predators, attack the pests in agro-ecosystem (Rotheray, 1989). Information about the NEs is critical for developing integrated pest management program especially for conservation and release of the beneficial organisms (Pedigo, 2002). Seasonal population dynamics of some predators of $A$. pinicae were previously studied in India (Mani \& Krishnamoorthy, 1995; Sreedevi et al., 2006) and Libya (Amin, 2002). However, no previous study has been performed about seasonal population fluctuations of $A$. punicae predators in Iran. Therefore, the objective of this study was to investigate seasonal population dynamics of the pest predators in southwest of Iran.

\section{Materials and Methods}

The research was carried out at an experimental pomegranate orchard, one hectare area, in Sirvan district, Ilam province, southwest of Iran (N 49 ${ }^{\circ}, 9^{\prime}, 12.299^{\prime}$, E 33, 33',52.535'). This orchards included 700 trees, six years old, of pomegranate, Punica granatum cv. Malase shirin. Cultural practices were carried out according to normal practice and no pesticides were applied during the study period.

Samplings were usually carried out at bi-weekly intervals from February 2016 to November 2017. At each sampling date, twenty trees were randomly chosen. From three heights $(1,1.5$ and $2 \mathrm{~m}$ ) of each main canopy direction (north, south, east and west), three shoots, and a total of 12 shoots from each sampled tree, were 
randomly taken. Therefore, in each sampling date, 240 pomegranate shoots were taken from 20 selected trees. The shoots were transported to laboratory, then species of the NES and their numbers were separately recorded under stereomicroscope.

\section{Results and Discussion}

Totally, four insect predators, Coccinella septempunctata L., Oenopia congelobata L. (Col., Coccinellidae), Xanthogramma pedisseguum Haris (Dip., Syrphidae) and Chrysoperla carnea Stephens (Neu., Chrysopidae), fed on S. ceratoniae colony in Sirvan district.

Seasonal population dynamics of the predators are shown in Figure 1. Among the species, the syrphid fly, X. pedisseguum, had the highest density. It was first observed in early of April 2016 and end of March 2017. Population density of the fly peaked at 20 and 21 April 2016 and 2017, respectively. Then, population density of the predator gradually decreased and no syrphid fly found in sampling at 21 May 2016 and 22 May 2017.

C. septempunctata presented in aphid colony during 21 March to 21 May 2016 and 21 March to 22 May 2017. Population peaks of the predator were recorded at 20 April 2016 and 21 April 2107. O. pedissequum was firstly observed at 4 April 2016 and 21 March 2017. The predator density rapidly increased and peaked at 20 April 2016 and 21 May 2017. No O. pedissequum was sampled after 21 May 2016 and 5 May 2017.

C. carnea was firstly sampled at 21 March 2016 and 2017. Population peaks of the predator occurred at 20 April 2016 and 21 May 2017. C. carnea was not observed after 20 April and 5 May 2016 and 2017, respectively.

Four species, Scymnus castaneus Sicard, S. latemaculatus Motschulsky, Monochilus sexmaculatus Fabricius (Col., Coccinellidae) and Paragus serratus Fabricius (Dip., Syrphidae) were reported as predator of $A$. punicae in India (Mani and
Krishnamoorthy, 1995). Also, eleven species of insect predators were collected from A. punicae in Lybia. The species belong to families Coccinellidae, Anthocoridae, Syrphidae, Cecidomyiidae and Chrysopidae. The predators occurred during two periods, the first period occurred from April to mid-June and the second period occurred from mid-September to early November (Amin, 2002). The first activity period of the predators is agree with our result. Natural enemies of sucking pests of pomegranate trees were investigated in India by Ananda (2007). They showed that five species of predators, Scymnus coccivora Ayyar, Cheilomenus sexmaculata Fabricius, Hippodomia variegate Geoze, C. septempunctata (Col., Coccinellidae) and $C$. carnea were collected from aphid colonies. The predators presented from December to March in pomegranate orchards. The different results may be due to different climate conditions of the research places. Some insect predators including $H$. variegate, Adalia tetraspilota Hope, Propylea luteopustulata Mul. (Col., Coccinellidae) and Syrphid flies was reports as predators of $A$. punicae in Kashmir (Khan et al., 2017). The major predators preyed on A. punicae in pomegranate ecosystem of Banglor, India, were Chilomenes sexmaculata Fabricius, Scymnus sp., Pseudaspidemerus circumflexo Motsch., P. serratus, Isciodon scutellaris Fabricius and Chrysopa sp. The aphidophagus insects showed two peaks, first peak was during January-February and second peak was during August-September (Sreedevi \& Verghese, 2007).

\section{Conclusions}

The activity period of the predators may be affected by aphid activity period or environmental conditions especially temperature and relative humidity $(\mathrm{RH})$. For all predators, the highest activity was occurred when the means of temperature and RH were 13-25 and less than $30 \%$. Sreedevi et al. (2006) demonstrated that abundance of $A$. punicae predators significantly affected by environmental factors especially temperature and $\mathrm{RH}$.

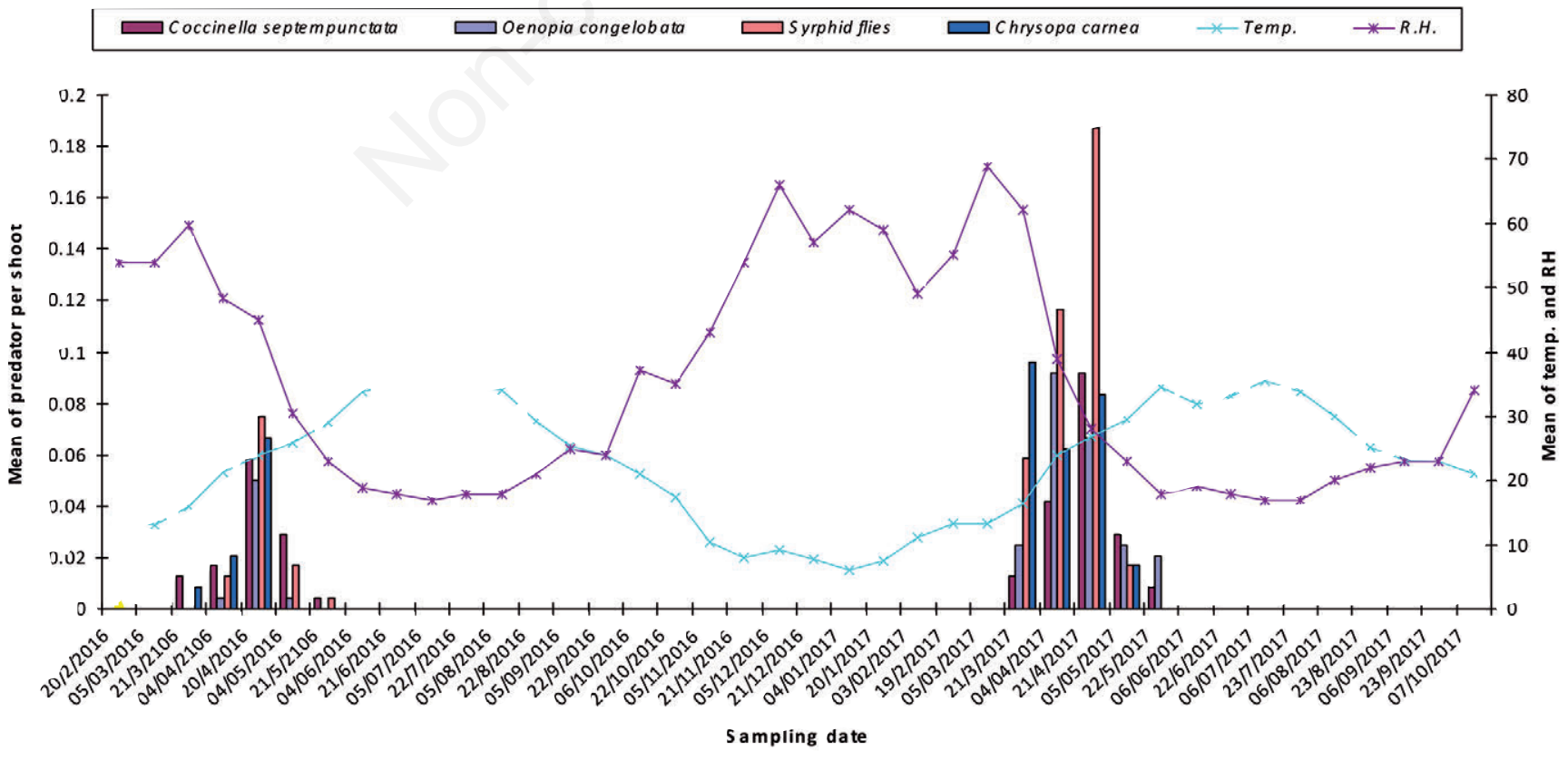

Figure 1. Seasonal population dynamics of Aphis punicae predators in pomegranate orchards of Sirvan district, southwest Iran. 


\section{References}

AHMADI M., POOR JAVAD N., 2016 - Biology and seasonal fluctuations of pomegranate aphid, Aphis punicae (Hem., Aphididae) in Isfahan. - J. Entomol. Soc. Iran 83: 181-8.

AMIN A.H., 2002 - Natural enemies of pomegranate aphid, Aphis punicae Passerini (Homoptera: Aphididae) at El-Beida Region, Libya. - Arab J. Plant Protect. 20: 150-3.

ANANDA N., 2007 - Seasonal incidence and management of sucking pests of pomegranate (Doctoral dissertation, UAS, Dharwad).

KHAN A.A., SHAH M.A., RIYAZ S. 2017 - Records of aphid and their natural enemies in agro-ecosystem with special reference to horticultural ecosystem of Kashmir. - J. Entomol. Zool. Stud. 5: 189-203.

MANI M., KRISHNAMOORTHY A., 1995. Natural enemies of Siphoninus phillyreae (Homoptera: Aleurodidae) and Aphis punicae (Homoptera: Aphididae) on pomegranate. Entomon 20: 31-4.
MOAWAD S.S., AL-BARTY A.M., 2011 - Evaluation of some medicinal and ornamental plant extracts toward pomegranate aphid, Aphis punicae (Passerini) under laboratory conditions. Afr. J. Agri. Res. 6: 2425-9.

ROTHERAY G.E., 1989 - Naturalist's Handbook: Aphid predators. Richmond Publishing Co., Slough, UK.

ROUHANI M., SAMIH M.A., IZADI H., MOHAMMADI E., 2013 - Toxicity of new insecticides against pomegranate aphid, Aphis punicae. - Int. Res. J. Appl. Basic Sci. 4: 496-501.

SMITH D., BROADLEY R.H., BEATTIE G.A.C., 1997 - Citrus pests and their natural enemies: Integrated pest management in Australia. - Hort. Res. Develop. Corp. 272 pp.

SREEDEVI K., VERGHESE A., 2007 - Ecology of aphidophagous predators in pomegranate ecosystem in India. Commun. Agr. Appl. Biol. Sci. 72: 509-16.

SREEDEVI K., VEREGHESE A., VASUDEV V., DEVI K.S., 2006 - Species composition and abundance of predators with reference to the pomegranate aphid, Aphis punicae Passerini. Pest Manag. Hort. Ecosys. 12: 93-7. 